Gastroia: Journal of Gastronomy and Travel Research, Vol. 5, Issue 3, 447-463, 2021

Restoran Çalışanların Covid-19 Korkusu ile Tükenmişlik Düzeyleri Arasındaki İlişkinin Belirlenmesi: Hatay

Örneği

Seyran REYHANDALI, Hasan CINNIOĞLU

\title{
Restoran Çalışanların Covid-19 Korkusu ile Tükenmișlik Düzeyleri Arasındaki İlişkinin Belirlenmesi: Hatay Örneği
}

Determining the Relationship Between the Fear of Covid-19 and Burnout Levels of Restaurant Employees: The Case of Hatay

* Seyran REYHANDALI

** Hasan CINNIIOĞLU

\section{GAS}

Yayın Bilgileri

Kabul tarihi: 10.07.2021

Yayın tarihi: 20.10 .2021

\section{Yazar İletişim Bilgileri \\ * seyranreyhandali.sbe20@iste.edu.tr \\ ** hasan.cinnioglu@iste.edu.tr}

\section{ÖZET}

$\mathrm{Bu}$ araştırmanın temel amacı; Hatay ilinde faaliyet gösteren restoran işletmesi çalışanlarının Covid19 korkusu ile tükenmişlik düzeyleri arasındaki ilişkiyi belirlemektir. Buna bağlı olarak çalışanlarda Covid-19 korkusunun tükenmişliğin alt boyutları olan duygusal tükenme, duyarsızlaşma ve düşük kişisel başarının çalışanlar üzerindeki etkilerini belirlemek bu çalışmanın alt amaçları arasında yer almaktadır. Covid-19 salgınını inceleyen birçok çalışma olmasına rağmen, restoran işletmeleri ve çalışanlarının tükenmişlik düzeylerini inceleyen sınırlı sayıda çalışma olması nedeniyle bu araştırma önem arz edebilmektedir. Araștırmanın evrenini Hatay ilinde faaliyet gösteren restoran ișletmeleri çalışanları oluşturmaktadır. Araştırmanın yapılması için seçilen bölgenin turizm potansiyeline sahip, gelişmekte olan bir bölge olması ve bununla beraber restoran işletmelerinin artış göstermesi nedeniyle Hatay ili tercih edilmiştir. Bu amacı gerçekleştirmek için Hatay ilinde faaliyet gösteren restoran işletmeleri çalışanlarından anket yöntemi ile veriler elde edilmiştir. Geliştirilen anket formu İskenderun Teknik Üniversitesi Etik Kurul onayından geçmiştir. Veriler 2021 yılı Mayıs-Haziran aylarında çevrimiçi ortamda (pandemi koşullarından dolayı) toplanmıştır. Restoran çalışan sayısının net olarak bilinmemesi nedeniyle sınırsız evren kabul edildiğinden örneklem olarak 384 kişi yeterli sayı olarak kabul edilmiş̧tir. Söz konusu işletmelerin içerisinde bulunduğumuz pandemi nedeniyle anketin yapıldığı dönemde birçok restoran işletmesi kapalı olduğundan toplamda 274 anket yapılabilmiştir. Elde edilen veriler sonucunda; çalışanların Covid-19 korkusu ve tükenmişlik düzeyleri arasında pozitif yönlü ve anlamlı bir ilişki olduğu tespit edilmiştir. Bununla birlikte tükenmişliğin alt boyutları açısından bakıldığında Covid-19 korkusu ile duygusal tükenme arasında pozitif yönlü ve anlamlı bir ilişki tespit edilmiştir. Aynı şekilde duyarsızlaşma arasında pozitif yönlü ve anlamlı bir ilişki tespit edilmiştir. Ancak bu ilişkilere rağmen Covid-19 korkusu ile kişisel başarı arasında herhangi bir ilişki tespit edilmemiştir.

Anahtar Kelimeler: Restoran İşletmeleri, Covid-19, Tükenmişlik

\section{ABSTRACT}

The main purpose of this research is; The aim of this study is to determine the relationship between the fear of Covid-19 and burnout levels of restaurant employees operating in Hatay. Accordingly, determining the effects of fear of Covid-19 on employees, emotional exhaustion, depersonalization and low personal achievement, which are sub-dimensions of burnout, are among the sub-objectives of this study. Although there are many studies examining the Covid-19 outbreak, this research is important because there are limited studies examining the burnout levels of restaurant businesses and their employees. The universe of the research consists of the employees of restaurant businesses operating in Hatay. The province of Hatay was preferred due to the fact that the region chosen for the research is a developing region with tourism potential and the increase in restaurant businesses. In order to achieve this aim, data were obtained from the employees of restaurant businesses operating in the province of Hatay by survey method. The developed questionnaire was approved by the Iskenderun Technical University Ethics Committee. Data were collected online (due to pandemic conditions) in May-June 2021. Since the number of restaurant employees is not known exactly, 384 people were accepted as a sufficient number as the sample, since it was accepted as an unlimited universe. Due to the pandemic we are in, a total of 274 surveys were made, as many restaurant businesses were closed during the survey period. As a result of the data obtained; It has been determined that there is a positive and significant relationship between the fear of Covid-19 and burnout levels of the employees. However, in terms of the sub-dimensions of burnout, a positive and significant relationship was found between the fear of Covid-19 and emotional exhaustion. Likewise, a positive and significant relationship was found between depersonalization..

Keywords: Restaurant Operations, Covid-19, Burnout 


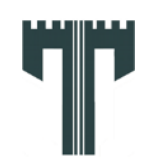

Gastroia: Journal of Gastronomy and Travel Research, Vol. 5, Issue 3, 447-463, 2021

Restoran Çalışanların Covid-19 Korkusu ile Tükenmişlik Düzeyleri Arasındaki İlişkinin Belirlenmesi: Hatay Örneğ $i$

Seyran REYHANDALI, Hasan CINNIOĞLU

\section{GíRiş}

Covid-19 salgını, Çin ülkesinin Vuhan kentinde Aralık 2019' da ortaya çıkan ve solunum yolu enfeksiyonlarına neden olan bir virüs olarak tanımlanmıştır. Dünya ülkelerini etkisi altına alan Covid-19 virüsünün Vuhan eyaletinde ilk olarak deniz ürünleri satan hayvan pazarında ortaya çıktığı görülmüş ve daha sonra insanlara bulaşarak tüm dünya ülkelerinde salgın yayılmaya başlamıştır (TC Sağlık Bakanlığı, 2020). Dünya Sağlık Örgütü, Koronavirüsü (Covid-19) 11 Mart 2020 durum raporunda pandemi olarak ilan etmiştir (WHO, 2020). Koranavirüs vaka sayılarının artması ile durumun önemini kavranmaya başlamış ve bazı tedbirlerin alınması kaçınılmaz olmuştur (Demir vd., 2020: 81). Koranavirüs salgını insanların, kurumların ve işletmelerin ekonomik ve sosyal gelişimini olumsuz yönde etkilemiştir (Sulkowski, 2020: 2). Covid-19 pandemisi ülkelerin ekonomisini, sosyal etkileşimini, yaşam kalitesini ve bununla birlikte işletme yapılarını da değiştirmiştir (Barua, 2020: 8). Türkiye'de Covid-19 salgınında ilk vakaların görülmesi ile insanlar sağlıkları için korkmaya ve endişelenmeye başlamıştır. Koranavirüs toplumu psikolojik, sosyal, politik ve ekonomik olarak birçok yönde etkilemiştir (Arpacı vd., 2020:1). Dünyada hızla yayılan Covid-19 salgını 2020 Mart ayında başlayarak etkisini tüm işletmelerde göstermeye başlamış ve diğer işletmeler gibi turizm işletmeleri de bu salgından dolayı faaliyetlerine ara vermek zorunda kalmıştır (Demir vd., 2020: 96). Pandemi sürecinde birçok turizm işletmesi finansal sorunlar yaşamış ve çok sayıda personelin işten çıkarıldığı gözlemlenmiştir (Atay, 2020: 168). Yiyecek içecek işletmeleri salgın sürecinde ekonomik ve sosyal etkileşim olarak negatif etkilenen sektörler arasında yerini almıştır. Turizm işletmelerinde sosyal etkileşimin yoğun olması nedeniyle özellikle yiyecek içecek sektörünün ülke yöneticileri tarafından koyulan kısıtlamalar sebebiyle en çok etkilenen sektörlerden biri olduğu görülmektedir (İflazoğlu ve Aksoy, 2020: 3363). Bu kısıtlamaların getirisi olarak iş kapasitesi düşmüş ve çalışan istihdamında denge sağlanamamıştır. Çalışma hayatında ki dengelerin bozulması, rutin işlerin yapılamaması, belirsizlik duygusu, Covid19'a yakalanma riski insanlarda strese, korkuya ve psikolojik olarak tükenmişliğe neden olabilmektedir. Bu noktada araştırmanın temel sorusu, Covid-19 korkusunun tükenmişlik düzeyi üzerinde bir etkisi var mıdır? Bu nedenle ilgili soruya yanıt arama ihtiyacı bu araştırma amacının belirleyicisi olmaktadır. Bu araştırmanın amacı, restoran çalışanlarındaki Covid-19 korkusunun tükenmişlik düzeyleri üzerindeki etkisini belirlemektir. Covid-19 salgınını inceleyen birçok çalışma olmasına rağmen, restoran işletmeleri ve çalışanlarının tükenmişlik düzeylerini inceleyen sınırlı sayıda çalışma olması sebebiyle literatüre sağlayacağı katkı açısından bu araştırma önem arz edebilmektedir. Araştırma amacını gerçekleştirmek üzere öncelikle konu ile ilgili kuramsal yapı oluşturulmuş ve ardından restoran çalışanlarından anket tekniği ile veriler toplanmıştır.

\section{KAVRAMSAL ÇERÇEVE}

\subsection{Covid-19}

Covid-19 Pandemisi ile ilgili ilk vaka 31 Aralık 2019'da Dünya Sağlık Örgütü Çin Ülke Ofisi'nde, Hubei Eyaletinin Vuhan şehrinde-tespit edilmiştir. Virüsün 7 0cak 2020'de daha önce insanlarda tespit edilmemiş yeni bir koranavirüs olduğu belirtilmiştir (Sağlık Bakanlığ1, 2020: 7). İlerleyen süreçte 2019-nCoV salgının adı Covid-19 olarak kabul edilmiş, virüs 


\section{$\|$}

Gastroia: Journal of Gastronomy and Travel Research, Vol. 5, Issue 3, 447-463, 2021

Restoran Çalışanların Covid-19 Korkusu ile Tükenmişlik Düzeyleri Arasındaki İlişkinin Belirlenmesi: Hatay Örneğ $i$

Seyran REYHANDALI, Hasan CINNIOĞLU

SARS CoV'e ye benzer olmasından dolayı SARS-CoV-2 olarak adlandırılmıştır (Sağlık Bakanlığı, 2020: 7). Covid-19 hastalığına, şiddetli akut solunum enfeksiyonlarına neden olan SARS-CoV2 virüsünün neden olduğu bilinmektedir (Bakar ve Rosbi, 2020: 189). Salgın damlacık yoluyla insanların birbiriyle etkileşim halinde olması nedeniyle yayılım göstermiştir (Gormeli ve Guneş, 2020: 1).

Küresel bir salgın olarak gelişen koranavirüs ülkeleri sadece sağlık yönünden değil politik, ekonomik, sosyal ve psikolojik olarak etkilemiştir (Üstün ve Özçiftçi, 2020:144). Dünyanın hızla gelişen hizmet sektörlerinden biri olan turizm ekonomik kriz, doğal afetler, salgın hastalıklar, yanlış politikalar nedeniyle birçok olumsuzluk ve kriz ile karşı karşıya kalmış ve etkileri turizm faaliyeti gösteren bölgelerde hissedilmiştir (Hall, 2010: 402). Birçok sektörde etkisini gösteren Covid-19 salgını yiyecek içecek sektörü içerisine faaliyet gösteren restoran işletmelerini de sekteye uğratmış ve birçok önlemin alınmasına sebep olmuştur. Alınan bu önlemler kapsamında insanlarda hijyen ve mesafe konusunda tereddütler yaşaması, işletmelerin kapatılıp paket servisine dönmesi, yiyecek içecek sektöründe finansal iş kayıpların olmasına neden olmuştur (Okat vd., 2020: 203). Yiyecek içecek işletmeleri salgın (Covid-19) sürecinde online sipariş, online ödeme ve self-servis uygulamalarının bu süreçte daha fazla ön plana çıktığı görülmektedir (Atay, 2020: 171). Bu süreçte birçok işletmede personel sayısında önemli derecede kayıplar yaşanmıştır. (Haywood, 2020: 600). İşletmelerin birçoğu faaliyetlerine ara verirken bir k1smı da asgari düzeyde personelle faaliyetlerini sürdürmüştür (Cinnioğlu, 2021: 36). Daha sonraki normalleşme sürecinde Türkiye'de faaliyet gösteren işletmelere uygulanan tedbirler (hijyen, mesafe vb.) kapsamında kurallar belirlenmiş olup faaliyetlerine devam etmeleri sağlanmıştır (Aydın ve Doğan, 2020: 106).

\subsection{Tükenmişlik}

Maslach'a göre, iş sürecinde sıklıkla insanlarla etkileşim halinde olunması, iş yükünün ve sorumluluklarının artması, bir sorunun çözümü karşısında belirsizlik ve başarısızlığın olması insanlarda strese, kaygıya ve tükenmişliğe neden olur (Maslac, Jackson, 1981: 99). Gann (1979: 3) tükenmişliği; çalışma ortamında oluşan stres faktörlerinin kişinin görevine yansıması ve belirsizlik yaşaması sonucu kişiyi psikolojik olarak etkileyen duygular olarak tanımlamıştır. Golembiewski vd. (1998: 60) göre tükenmişliğin işletme yapılarında birtakım değişikliklere sebep olduğu ve buna etken olarak yaşam kalitesinin düşmesi, iş performans1 ve örgütsel bağlılığın azalması, aile yapısının bozulması, sağlık sorunların artması gibi olumsuz etkilerin olduğunu belirtmiştir. Rada ve Charmina (2004: 790) tükenmişliği, insanların çalışma hayatı boyunca kariyer hedeflerine ulaşmak için yaşadığı stres sonucu yavaş yavaş manevi olarak yıpranması olarak tanımlamışlardır. Budak ve Sürgevil (2005:95) tükenmişliği, insanların iş yaşamında etkileşim sonucu yaşamış oldukları '"ruhsal ve fiziksel açıdan enerjinin tükenmesi' 'şeklinde tanımlamıştır. Chohan vd. göre, kişinin uzun çalışma saatlerine bağlı olarak oluşan fiziksel ve psikolojik etkilerinin sebep olduğu yorgunluk, iş stresi, iş performansının düşüklüğü ve moral bozukluğu tükenmişlik olarak belirtilmiştir (Chohan vd., 2020: 2)

Maslac ve Jackson tükenmişliği duygusal tükenme, duyarsızlaşma ve kişisel başarının azalması olarak alt boyutlara ayırmıştır (Maslac ve Jackson, 1981: 99). Tükenmişliğin artmasının nedenlerinden biri olan duygusal tükenme, insanların iş yükünün artması ile 


\section{$\|$}

Gastroia: Journal of Gastronomy and Travel Research, Vol. 5, Issue 3, 447-463, 2021

Restoran Çalışanların Covid-19 Korkusu ile Tükenmişlik Düzeyleri Arasındaki İlişkinin Belirlenmesi: Hatay Örneğ $i$

Seyran REYHANDALI, Hasan CINNIOĞLU

kendini psikolojik olarak yetersiz hissetmesidir. Tükenmişliğin başka boyutu olan duyarsızlaşma, insanların iş gereklerini yerine getirirken hizmet verdiği kişilere olumsuz ve duygusuz biçimde davranış sergilemeleridir. Kişisel başarının azalması ise kişinin işyerindeki veya hizmet verdiği insanlarla ilgili sorunların üstesinden gelemiyor olması sonucu, kendini yetersiz ve mutsuz hissetmesidir (Maslac vd., 1996: 192).

Turizm işletmelerinde üretimin ve tüketimin aynı anda gerçekleşiyor olması nedeniyle çalışanların müşteri memnuniyetini sağlamak için daha fazla performans gösterilmesi gerekmektedir (Cinnioğlu, Atay ve Karakaş 2019: 158). Turizm işletmelerinde hizmet üreticilerinin yoğun çalışma saatleri, iş stresi, performans düşüklügüne, tükenmişliğe neden olabilmektedir. Dolayısıyla işten ayrılma niyetleri artmakta ve işletmede verimliliğin düşmesine yol açabilmektedir (Birdir ve Tepeci, 2003: 96 ). İşletme sahipleri ve çalışanlar arasında yazılı olmayan karşılıklı beklentilerin olması (psikolojik sözleşme) ve bu beklentilerin karşılanmaması durumunda çalışanların stres, işgücü kaybı ve buna bağlı olarak tükenmişlik gibi olumsuz davranış sergilemeleri kaçınılmaz olabilmektedir (Cinnioğlu vd., 2017: 45). Turizm sektörünün emek yoğun bir özelliğe sahip olması, esnek ve fazla mesai gibi nedenlerden dolayı işgörenlerin verimli çalışabilmesi ve işletmedeki başarısını koruyabilmesi için fazla performans sergilemesi, çalışanda psikolojik yıpranmalara neden olabilmektedir. Bunun bir sonucu olarak işletmenin hizmet kalitesinin düşmesine neden olmakla beraber mesleki olarak kendini yetersiz hissetmesine neden olabilmektedir. Hizmet sektöründeki yoğunluk işten ayrılma niyetinin yüksek olmasına ve duygusal olarak kendini tükenmiş hissetmesine neden olmaktadır (Çelik ve Saçlı, 2013: 361362; Cinnioğlu ve Salha, 2007: 601).

\subsection{Covid-19 ve Tükenmişlik}

Küresel boyutta yayılan Covid-19 salgını devlet, toplum, meslek, cinsiyet, yaş farkı gözetmeden tüm dünyayı etkisi altına almış, insanların fizyolojik, ekonomik ve psikolojik yapılarını değiştirmiştir (Polizzi vd. 2020: 59). İnsanların psikolojik ve fizyolojik olarak mesleklerinden uzaklaşması, stres ve belirsizliğin yaşam ve hizmet kalitesine yansıması tükenmişliğin belirtileri arasında gösterilmektedir (Kaçmaz, 2005: 29). Tüm ülkede bütün iş alanlarına önemli etkisi olan Covid-19 turizm işletmelerini de derinden etkilemiştir. Turizm işletmelerinin kapalı olması, gelir kaybının yaşanmasına ve birçok çalışanın işsiz kalmasına neden olmuştur (Alaeddinoğlu ve Rol, 2020: 235). Buna bağlı olarak çalışanlarda oluşan geçim ve sektörel gelecek kaygısı, kendine yetememe gibi durumların yaşanması, tükenmişliği de beraberinde getirmiştir. Tükenmişliğin salgın sürecinde yoğun biçimde çalışan insanlar üzerinde etkili olduğu görülmektedir (Morina ve Avdimetaj, 2020: 317).

Koranavirüsün insanlarda bedenen ve ruhen tahribatlara, umutsuzluğa ve tükenmişliğe neden olduğu öngörülmektedir (Uluğ, 2020: 3). Pandemi sürecinde ölüm vakalarının artması işletmeleri ve çalışanları olumsuz yönde etkilemiştir (Üstün ve Özçiftçi, 2020:148). $\mathrm{Bu}$ süreçte işletmelerin ve çalışanların yeni düzene alışmaları kaygı, belirsizlik ve tükenmişliğe neden olabilmektedir. Covid-19 süreci ve normalleşme sonrasında uygulanan kısıtlamalar neticesinde işletmelerin devamlılığını sağlayabilmesi (Cinnioğlu, 2020: 36) ve iş gören istihdamını tam kapasite olarak devam ettirmesi finansal açıdan zor görünmektedir. $\mathrm{Bu}$ kapsamda pandemi sürecinde alınan kararlar işletmelerinin çoğunun hizmetlerini durdurması veya iş kapasitesini düşürmesi, birçok insanın işten çıkarılması gibi sorunlar, 


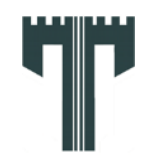

Gastroia: Journal of Gastronomy and Travel Research, Vol. 5, Issue 3, 447-463, 2021

Restoran Çalışanların Covid-19 Korkusu ile Tükenmişlik Düzeyleri Arasındaki İlişkinin Belirlenmesi: Hatay Örneğ $i$

Seyran REYHANDALI, Hasan CINNIOĞLU

çalışanlarda finansal güvensizliğin yanı sıra geleceğe yönelik belirsizlik yaşamalarına da neden olabilmektedir (Griffith, 2020: 2). Covid-19 salgınının çıkış nedeninin henüz bilinmemesi toplumun sosyo-ekonomik değerlerini etkilemekle beraber insanlarda korku, gelecek kaygısı, tükenmişlik gibi psikolojik çöküşler yaşamasına sebep olmuştur (Bozkurt vd. 2020: 305).

Yukarıdaki bilgilere bağlı olarak Covid-19'un restoran çalışanları üzerinde tükenmişlik duygusuna neden olabileceği öngörülmektedir. Buna bağlı olarak araştırmada aşağıdaki hipotezler geliştirilmiştir.

H1: Covid-19 korkusunun tükenmişlik üzerinde anlamlı bir etkisi vardır.

H1a: Covid-19 korkusunun duyarsızlaşma üzerinde anlamlı bir etkisi vardır.

H1b: Covid-19 korkusunun duygusal tükenme üzerinde anlamlı bir etkisi vardır.

H1c: Covid-19 korkusunun kişisel başarı üzerinde anlamlı bir etkisi vardır.

Araştırmada geliştirilen hipotezlere bağlı olarak araştırmanın modeli aşağıdaki gibi oluşturulmuştur.

Şekil 1: Araştırmanın Grafiksel Modeli

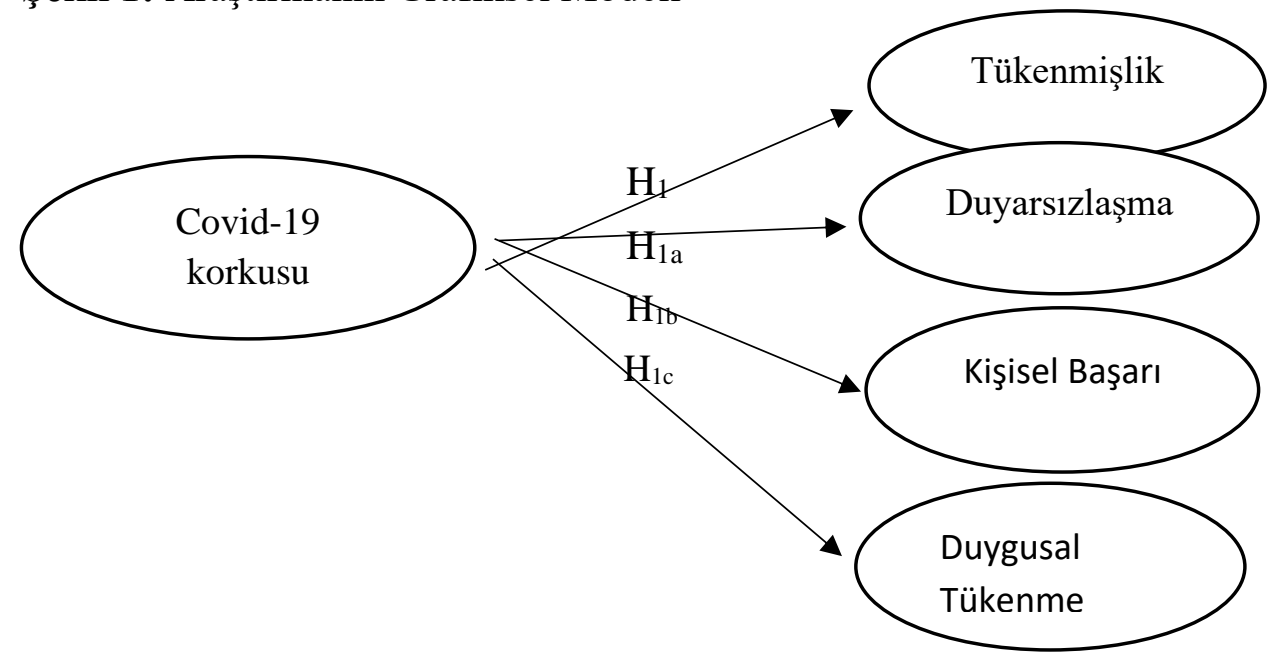

\section{YÖNTEM}

$\mathrm{Bu}$ araştırma yöntem açısından nicel, amacı açısından ise açıklayıcı bir çalışmadır Nicel yöntemle yapılan bu araştırmada genel tarama modellerinden ilişkisel tarama modeli kullanılmıştır. Yöntem kısmında araştırmanın amacı ve önemi açıklanarak, araştırmada kullanılan veri toplama aracına, araştırmanın evren ve örneklemine yer verilmiştir.

\subsection{Araştırmanın Amacı ve Önemi}

Turizm işletmeleri yapısı gereği hizmet odaklı ve hassas olması nedeni ile siyasi olaylar, finansal krizler, salgın hastalıklar, terörizm ve sosyal olaylardan en fazla etkilenen sektörler arasında yer almaktadır (Köşker, 2017: 216). Günümüzde tüm dünyayı etkisi altına alan Covid-19 salgını tüm işletmeler gibi restoran işletmelerini de derinden etkilemiş ve iş görenlerin ekonomik ve psikolojik olarak çöküşler yaşamasına sebep olmuştur. Bu sebeple araştırmanın amacı restoran çalışanlarındaki covid-19 korkusunun tükenmişlik düzeyleri 


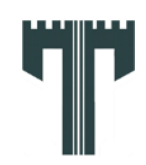

Gastroia: Journal of Gastronomy and Travel Research, Vol. 5, Issue 3, 447-463, 2021

Restoran Çalışanların Covid-19 Korkusu ile Tükenmişlik Düzeyleri Arasındaki İlişkinin Belirlenmesi: Hatay Örneğ $i$

Seyran REYHANDALI, Hasan CINNIOĞLU

üzerindeki etkisini belirlemektir. Buna bağlı olarak çalışanlarda Covid-19 korkusunun tükenmişliğin alt boyutları olan duygusal tükenme, duyarsızlaşma ve düşük kişisel başarının çalışanlar üzerindeki etkilerini belirlemek bu çalışmanın alt amaçları arasında yer almaktadır. Alanyazında Covid-19 salgınını inceleyen birçok çalışma olmasına rağmen, restoran işletmeleri ve çalışanlarının tükenmişlik düzeylerini inceleyen fazla çalışmaya rastlanılmamış olması sebebiyle, bu çalışmanın alan yazınına katkı sağlayacağı ve sonraki çalışmalara yol gösterici olacağı öngörülmektedir. Bu durum aynı zamanda çalışmanın önemine dikkat çekmektedir.

\subsection{Evren ve Örneklem}

Araştırmanın evrenini Hatay ilinde faaliyet gösteren restoran işletmeleri çalışanları oluşturmaktadır. Araştırmanın yapılması için seçilen bölgenin turizm potansiyeline sahip, gelişmekte olan bir bölge olması ve bununla beraber restoran işletmelerinin artış göstermesi nedeniyle Hatay ili tercih edilmiştir. Zaman ve maliyet gibi kısıtlılıklardan dolayı evren üzerinden örneklem alınmıştır Örneklem büyüklüğünün belirlenmesinde ise bu restoranlarda çalışan kişi sayısı net olarak bilinmediğinden evren sınırsız olarak kabul edilmiş ve bu durumda örneklem büyüklüğü 384 kişi olarak belirlenmiştir (Ural ve Kılıç, 2013: 43). Veriler 2021 Mayıs-Haziran aylarında toplanmıştır. İçerisinde bulunulan pandemi nedeniyle anketin yapıldığı söz konusu dönemde birçok restoran işletmesinin kapalı olması sebebiyle toplamda 301 anket elde edilmiş ancak eksik ve hatalı anketlerin çıkarılması sonucunda 274 anket analize dahil edilmiştir. Bu nedenle veriler \% 95 güven aralığında ve $\pm \% 8$ örneklem hatası aralığında değerlendirilmiştir. Buna bağlı olarak araştırmanın örneklemini ise basit tesadüfi yöntemle seçilen 274 restoran çalışanı ile çevrimiçi ortamda (pandemi koşullarından dolay1) anket toplanmıştır.

\subsection{Veri Toplama Aracı}

Nicel desenli bu araştırmanın verilerinin toplanmasında araç olarak anket formları kullanılmıştır. Anket formları için İskenderun Teknik Üniversitesi Etik Kurul onayı alınıp veri toplama sürecine geçilmiştir. Anket 3 bölümden oluşmaktadır. Anketin ilk bölümünde restoran çalışanlarının pandemi sürecinde korku düzeylerini belirlemek için 'Covid-19 korku ölçeği' ikinci bölümde tükenmişlik düzeylerini belirlemek için 'Maslach Tükenmişlik Ölçeği' kullanılmış olup üçüncü bölümde ise demografik bilgilere yer verilmiştir. Araştırmada kullanılan ölçekler aşağıda açıklanmıştır.

\subsection{Covid-19 Korkusu Ölçeği}

Covid-19 korkusu ölçeği Ahorsu vd., (2020) tarafından geliştirilmiş, 7 madde ve tek boyuttan oluşan bir ölçek olup pandemi sürecinde korku düzeyini belirlemeyi amaçlamaktadır. Ölçeğin Türkçeye uyarlanması Satıcı vd.(2020: 2) tarafından yapılmıştır. Ölçekteki bazı maddeler şu şekildedir: ' En çok Covid-19'dan korkuyorum', ,'Covid-19 nedeniyle hayatımı kaybetmekten korkuyorum', 'Covid-19'u düşünmek beni rahatsız ediyor', 5'li yanıt kategorileri likert tipinde (1: Kesinlikle katılmıyorum ve 5: Kesinlikle kat1liyorum) derecelendirme sistemine sahiptir. 
Gastroia: Journal of Gastronomy and Travel Research, Vol. 5, Issue 3, 447-463, 2021

Restoran Çalışanların Covid-19 Korkusu ile Tükenmişlik Düzeyleri Arasındaki İlişkinin Belirlenmesi: Hatay Örneğ $i$

Seyran REYHANDALI, Hasan CINNIOĞLU

\subsection{Maslach Tükemişlik Envanteri (Maslach Burnout Inventory-MBI)}

Araştırmada çalışanların tükenmişlik düzeylerini ölçmek için Maslach ve Jackson (1981) tarafından geliştirilen Maslach Tükemişlik Envanteri kullanılmıştır. Ölçek, toplam 22 ifadeden ve 3 alt boyuttan oluşmaktadır. Bu boyutlar, 'Duygusal tükenmişlik' (9), 'Duyarsızlaşma' (5) ve 'Kişisel başarının azalması' (8) şeklindedir. Ölçekteki bazı ifadeler şu şekildedir: 'Kendimi işimden duygusal olarak uzaklaşmış hissediyorum', İşimin beni kısıtladığını hissediyorum", "İnsanlarla yakın bir çalışmadan sonra kendimi canlanmış hissederim,", 'İ̧sim aracılığıyla insanların yaşamına katkıda bulunduğuma inanıyorum,'. Ölçek için kullanılan yanıt kategorileri ise "1-Hiçbir zaman, 2-Çok nadir, 3-Bazen, 4-Çoğu zaman ve 5-Her zaman" şeklinde derecelendirilmiştir. Bu doğrultuda duygusal tükenme ve duyarsızlaşma boyutunun yüksek, kişisel başarı boyutunun ise düşük çıkması tükenmişliği göstermektedir (Pelit ve Türkmen 2008: 125).

\subsection{Bulgular}

Araştırmada analizler yapılmadan önce verilerin çarpıklık ve basıklık değerleri belirlenmiş ve buna göre araştırma verilerinin normal dağılım gösterdiği tespit edilmiştir. Bu nedenle verilerin analizinde parametrik testlerden yararlanılmıştır.

Tablo 1. Katılımcılara Yönelik Demografik Bilgiler

\begin{tabular}{|c|c|c|c|c|c|}
\hline Cinsiyet & $\mathbf{f}$ & $\%$ & Turizm Eğitimi & $\mathbf{F}$ & $\%$ \\
\hline Kadın & 63 & 23 & Var & 54 & 19,7 \\
\hline Erkek & 211 & 77 & Yok & 220 & 80,3 \\
\hline Toplam & 274 & 100,0 & Toplam & 274 & 100,0 \\
\hline Doğum Tarihi & f & $\%$ & Çalıșma Süresi & $\mathbf{F}$ & $\%$ \\
\hline $18-27$ & 78 & 28,5 & 1 y1ldan az & 36 & 13,1 \\
\hline $28-39$ & 115 & 42,0 & $1-3$ y1l & 66 & 24,1 \\
\hline $40-49$ & 56 & 20,4 & 4- 6 y1l & 80 & 29,2 \\
\hline $50-59$ & 20 & 7,3 & 7- 9 y1l & 43 & 15,7 \\
\hline 60 yaş ve üzeri & 5 & 1,8 & 10 y1l ve üstü & 49 & 17,9 \\
\hline Toplam & 274 & 100,0 & Toplam & 274 & 100,0 \\
\hline Gelir Düzeyi & $\mathbf{f}$ & $\%$ & \multirow[t]{2}{*}{ Eğitim Durumu } & \multirow[t]{2}{*}{$\mathrm{f}$} & \multirow[t]{2}{*}{$\%$} \\
\hline $2826 \mathrm{TL}$ & 87 & 31,8 & & & \\
\hline $2827-3500$ & 53 & 19,3 & İlkokul & 42 & 15,3 \\
\hline $3501-4500 \mathrm{TL}$ & 52 & 19,0 & Ortaokul & 22 & 8,0 \\
\hline $4501-5500 \mathrm{TL}$ & 21 & 7,7 & Lise & 68 & 24,8 \\
\hline 5501 TL ve üzeri & 61 & 22,3 & Ön Lisans ( 2 y1llık) & 43 & 15,7 \\
\hline Toplam & 274 & 100,0 & Lisans ( 4 y1llık) & 88 & 32,1 \\
\hline Medeni Durum & f & $\%$ & Lisansüstü & 11 & 4,0 \\
\hline
\end{tabular}


Gastroia: Journal of Gastronomy and Travel Research, Vol. 5, Issue 3, 447-463, 2021

Restoran Çalışanların Covid-19 Korkusu ile Tükenmişlik Düzeyleri Arasındaki İlişkinin Belirlenmesi: Hatay Örneği

Seyran REYHANDALI, Hasan CINNIOĞLU

\begin{tabular}{|l|l|l|l|l|l|}
\hline Bekâr & 124 & 45,3 & Total & 274 & 100,0 \\
\hline Evli & 150 & 54,7 & & & \\
\hline Toplam & 274 & 100,0 & & & \\
\hline
\end{tabular}

Çalışmada öncelikle katılımcıların demografik bilgileri analiz edilmiş ve sonuçlar Tablo 1 'de verilmiştir. Katılımcıların demografik özelliklerine ilişkin bulguların yer aldığı Tablo 1 incelendiğinde, katılımcıların \%77'sinin erkek (f: 211), \%42'sinin 28-39 yaş aralığına sahip (f: 115) ve \%31,8'inin 2828 TL gelire (f: 87) sahip olduğu görülmektedir. Aynı zamanda katılımcıların \%54,7'sinin (f: 150) evli olduğu, \%80,3'ünün turizm eğitimine (f: 220) sahip olmadığı, \%29,2'sinin dört ile altı yıl arasında (f: 80) mevcut işletmede çalıştığ1 ve son olarak \%32'sinin lisans (f: 88) mezunu olduğu belirlenmiştir.

Faktör analizi değişkenler arası korelasyon katsayıları aracılığıyla çok sayıdaki değişken arasında ilişkiyi inceler; daha az sayıda faktöre dönüştürülmesine yardımcı olur'" (Yükselen, 2017: 217). Öncelikle araştırmada kullanılan ölçeklerin yapı geçerliliğini ortaya koymak için açıklayıcı faktör analizi yapılmış ve sonuçlar Tablo 2'de verilmiştir.

Tükenmişlik ölçeğine yönelik olarak yapılan açımlayıcı faktör analizi neticesinde ölçeğin KMO (Kaiser-Meyer-Olkin Measure) değerinin 0,885 ve Bartlett's test değerlerinin ise anlamlı olduğu $(\mathrm{p}=, 000)$ tespit edilmiştir. Faktör analizi sonucunda özdeğeri birden büyük üç alt boyut belirlenmiş olup, birlikte açıkladıkları toplam varyans \% 52,051'dir. Belirlenen alt boyutları ölçeğin orijinaline bağlı kalınarak isimlendirilmiştir. 


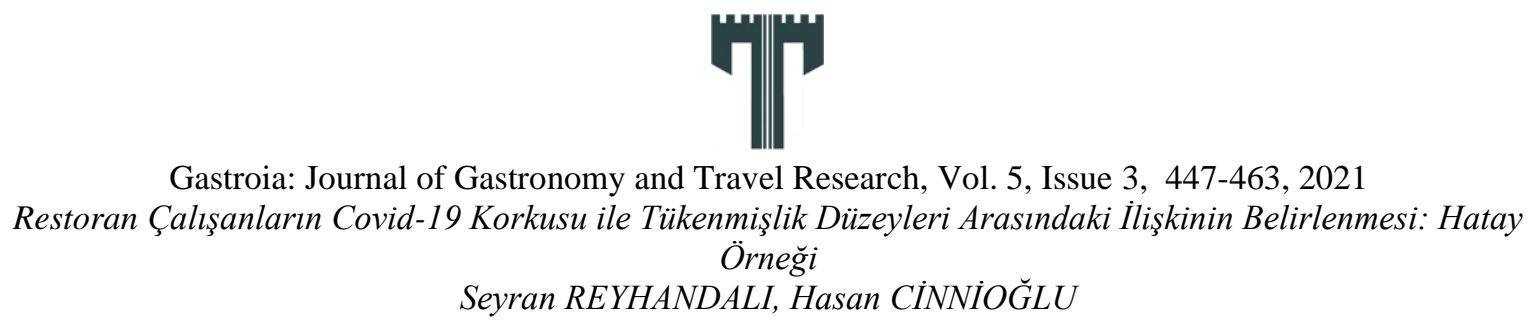

Seyran REYHANDALI, Hasan CINNIOĞLU

Tablo 2. Tükenmişlik Ölçeğine Yönelik Açımlayıcı Faktör Analizi

Tükenmişlik

Faktör Açıklanan

yükleri varyans (\%)

\section{Duygusal Tükenme}

İşimden dolayı kendimi tükenmiş hissediyorum.

Sabah kalktığımda yeni işgününü düşündüğümde kendimi bitkin hissediyorum

Bütün gün insanlarla çalışmak benim için çok yıpratıcı

Kendimi işgününün sonunda tükenmiş hissediyorum

İşimin beni hayal kırıklığına uğrattığını düşünüyorum.

İşim gereği insanlarla doğrudan doğruya çalışmak bende strese neden oluyor.

İşimin beni kısıtladı̆̆ını hissediyorum.

, 709

Kendimi işimden duygusal olarak uzaklaşmış hissediyorum

, 701

İşim için çok çalıştığımı düşünüyorum.

, 639

, 489

\section{Düşük Kişisel Başarı}

İşim gereği karşılaştığım insanlarla aramda rahat bir atmosfer yaratırım.

İşim aracılığıyla insanların yaşamına katkıda bulunduğuma inanıyorum.

İnsanlarla yakın bir çalışmadan sonra kendimi canlanmış hissederim.

İşim gereği karşılaştığım insanların sorunlarına en uygun çözüm yollarını bulurum

Bu iste birçok kayda değer başarı elde ettim.

İşim gereği karşılaştığım insanlarla çalıştıktan sonra kendimi canlanmış hissediyorum.

İşim gereği karşılaştığım kişilerin ne hissettiğini kolayca anlayabilirim.

İşimden kaynaklanan duygusal problemlerin soğukkanlılıkla üstesinden gelirim.

, 648

, 606

, 600

, 575

\section{Duyarsızlaşma}

Bu işe başladığımdan beri insanlara karşı daha duygusuz olduğumu düşünüyorum

İşim gereği karşılaştığım bazı kimselere sanki insan değillermiş gibi davrandığımı fark ediyorum

Bu işin duygusal olarak beni katılaştırmasından endişe duyuyorum.

İşim gereği karşılaştığım insanların bazı problemlerini sanki ben yaratmışım gibi davrandıklarını hissediyorum.

İşim gereği karşılaştığım insanların başlarına ne geldiği beni ilgilendirmiyor.

KMO:, $885 \quad \mathrm{p}=, 000 \quad$ Bartlett's Test: $1,045 \mathrm{E} 4$ 


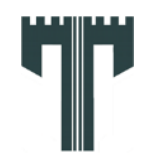

Gastroia: Journal of Gastronomy and Travel Research, Vol. 5, Issue 3, 447-463, 2021

Restoran Çalışanların Covid-19 Korkusu ile Tükenmişlik Düzeyleri Arasındaki İlişkinin Belirlenmesi: Hatay Örneğ $i$

Seyran REYHANDALI, Hasan CINNIOĞLU

Tablo 3. Covid-19 Korkusu Ölçeğine Yönelik Açımlayıcı Faktör Analizi

\begin{tabular}{|c|c|c|c|}
\hline Covid-19 Korkusu Ölçeği & $\begin{array}{l}\text { Faktör } \\
\text { Yükleri }\end{array}$ & $\begin{array}{c}\text { Açıklanan } \\
\text { Varyans } \\
(\%)\end{array}$ & Özdeğeı \\
\hline Covid-19 nedeniyle hayatım1 kaybetmekten korkuyorum. &, 804 & \multirow{7}{*}{56,268} & \multirow{7}{*}{3,39} \\
\hline Covid-19 kapmayı düşündüğümde kalbim hızla çarpıyor. &, 787 & & \\
\hline Covid-19 kapma konusunda endişelendiğim için uyuyamıorum. &, 787 & & \\
\hline $\begin{array}{l}\text { Sosyal medyada Covid-19 ile ilgili haberleri ve hikayeleri izlerken } \\
\text { gergin veya endişeli oluyorum }\end{array}$ &, 787 & & \\
\hline Covid-19'u düşündüğümde ellerim nemli oluyor. &, 734 & & \\
\hline En çok Covid-19'dan korkuyorum. &, 721 & & \\
\hline Covid-19'u düşünmek beni rahatsız ediyor. &, 613 & & \\
\hline Bartlett's Test: 877,115 & & & \\
\hline
\end{tabular}

Covid-19 korkusu ölçeğine yönelik açımlayıcı faktör analizi sonuçları Tablo 3 'te verilmiştir. Yapılan analiz neticesinde Covid-19 korkusu ölçeği KMO değer 0,867, Bartlett's testi anlamlılık sonucunun ise 0,000 olduğu tespit edilmiştir. Tek boyut altında toplanan yedi ifadenin açıkladığı toplam varyans oranı ise \%56,268'dir.

Araştırmada kullanılan ölçeklere yönelik faktör analizleri yapıldıktan sonra bu faktörlerin güvenirlilik düzeyleri belirlenmiş ve Tablo 4'te gösterilmiştir.

Tablo 4. Değişkenlerin Ortalama ve Cronbach's Alfa Değerleri

\begin{tabular}{|l|l|c|c|c|c|}
\hline & $\mathrm{n}$ & İfade Sayıs1 & Cronbach's Alfa & Ort. & Std. Sapma \\
\hline 1)- Duygusal Tükenme & 274 & 9 &, 884 & 2,75 &, 900 \\
\hline 2)- Düşük Kişisel Başar1 & 274 & 8 &, 813 & 3,70 &, 683 \\
\hline 3)- Duyarsızlaşma & 274 & 5 &, 779 & 2,39 &, 904 \\
\hline 4)- Tükenmişlik & 274 & 22 &, 835 & 3,02 &, 555 \\
\hline 5)- Covid-19 Korkusu & 274 & 7 &, 866 & 2,60 &, 903 \\
\hline
\end{tabular}

Ölçeklerin Cronbach's Alfa değerlerine bakıldığında tükenmişlik ölçeğinin 0,835 ve Covid19 korkusu ölçeğinin ise 0,866 olduğu tespit edilmiştir. Bu verilere göre araştırmada kullanılan ölçeklerin ve alt boyutlarının güvenirlilik düzeyinin yüksek olduğu (Cronbach’s Alfa $\geq 0.60$ ) söylenebilir (İslamoğlu ve Alnıaçık 2014: 283). Aynı tabloda yer alan değişkenlere yönelik ortalama değerlere bakıldığında ise çalışanların tükenmişlik düzeylerinin orta seviyede $(3,02)$ olduğu tespit edilmiştir. Aynı zamanda tükenmişlik 
Gastroia: Journal of Gastronomy and Travel Research, Vol. 5, Issue 3, 447-463, 2021

Restoran Çalışanların Covid-19 Korkusu ile Tükenmişlik Düzeyleri Arasındaki İlişkinin Belirlenmesi: Hatay Örneğ $i$

Seyran REYHANDALI, Hasan CINNIOĞLU

ölçeğinin alt boyutlarının da orta düzeyde olduğu belirlenmiştir. Bununla birlikte

katılımcıların Covid-19 korku düzeylerinin ise yine orta düzeyde $(2,60)$ olduğu görülmektedir.

Tablo 5. Değişkenler Arasındaki İlişkiye Yönelik Korelasyon Analizi Sonuçları

\begin{tabular}{|l|c|c|c|c|c|}
\hline Değişkenler & $\mathbf{1}$ & $\mathbf{2}$ & $\mathbf{3}$ & $\mathbf{4}$ & $\mathbf{5}$ \\
\hline 1)- Duygusal Tükenme & 1 & & & & \\
2)- Düşük Kişisel Başarı &, $130^{* *}$ & 1 & & & \\
3)- Duyarsızlaşma &, $468^{* *}$ &, $218^{* *}$ & 1 & & \\
4)- Tükenmişlik &, $823^{* *}$ &, $441^{* *}$ &, $696^{* *}$ & 1 & 1 \\
5)- Covid-19 Korkusu &, $332^{* *}$ &, 060 &, $215^{* *}$ &, $326^{* *}$ & \\
\hline **.p p $<001$ değerinde anlaml. & \multicolumn{7}{|l}{} \\
\hline
\end{tabular}

Değişkenler arasındaki ilişkiye yönelik korelasyon analizi sonuçlarının yer aldığı Tablo 5 incelendiğinde Covid-19 korkusu ile tükenmişlik düzeyi arasında pozitif yönlü ve anlamlı (r: ,326; $\mathrm{p}<.001)$ bir ilişki olduğu görülmektedir. Analiz sonuçlarına tükenmişliğin alt boyutları açısından bakıldığında Covid-19 korkusu ile duygusal tükenme arasında pozitif yönlü ve anlamlı (r: ,332; p <.001), yine aynı şekilde duyarsılaşma arasında pozitif yönlü ve anlamlı (r: ,215; p <.001) bir ilişki tespit edilmiştir (İslamoğlu ve Alnıaçık, 2014: 260). Ancak bu ilişkilere rağmen Covid-19 korkusu ile kişisel başarı arasında herhangi bir ilişki olmadığ 1 için etkiye bakılması söz konusu olmadığ 1 için, $\mathrm{H}_{3}$ hipotezi ret edilmiştir.

Covid-19 korkusunun çalışanların tükenmişlik düzeyine etkisine yönelik basit doğrusal regresyon analizi sonuçları Tablo 6'da verilmiştir. Analiz sonuçlarına göre Covid-19 korkusu tükenmişlik düzeyindeki değişimin \% 10'nunu $\left(\mathrm{R}^{2}=, 106\right)$, duygusal tükenmişlikteki değişimin \% 11 'ini $\left(\mathrm{R}^{2}=, 110\right)$ ve duyarsızlaşmadaki değişimin \% 4'ünü $\left(\mathrm{R}^{2}=, 046\right)$ açıkladığı tespit edilmiştir. Bununla birlikte ANOVA testi sonuçlarına göre tüm regresyon modellerin anlamlı olduğu belirlenmiştir $(\mathrm{p}=, 000)$. Aynı zamanda tüm modellerin Durbin-Watson (DW) Katsayısı 1,5 ile 2,5 arasında olması değişkenler arasında otokorelasyon sorununun ve VIF değerlerinin ise 1 olması çoklu doğrusal bağımlılık sorununun olmadığını göstermektedir (İslamoğlu ve Alnıç̧ı, 2014: 369). Tüm bu analizler 1şı ğında araştırmada geliştirilen $\mathrm{H} 1, \mathrm{H} 1 \mathrm{a}$ ve H1b hipotezlerinin kabul edildiği istatistiksel olarak ifade edilebilir. 


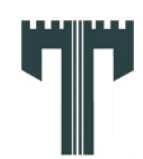

Gastroia: Journal of Gastronomy and Travel Research, Vol. 5, Issue 3, 447-463, 2021

Restoran Çalışanların Covid-19 Korkusu ile Tükenmişlik Düzeyleri Arasındaki İlişkinin Belirlenmesi: Hatay Örneğ $i$

Seyran REYHANDALI, Hasan CINNIOĞLU

Tablo 6. Covid-19 Korkusunun Çalışanların Tükenmişlik Düzeyine Etkisine Yönelik Basit Doğrusal Regresyon Analizi

\begin{tabular}{|c|c|c|c|c|c|c|}
\hline \multirow{2}{*}{\multicolumn{2}{|c|}{ Model }} & \multicolumn{2}{|c|}{$\begin{array}{c}\text { Standartlaştırılmamış } \\
\text { Katsayılar }\end{array}$} & \multirow{3}{*}{\begin{tabular}{|c|}
$\begin{array}{c}\text { Standartlaştırılmıs } \\
\text { Katsayılar }\end{array}$ \\
Beta \\
\end{tabular}} & \multirow{3}{*}{$\frac{\mathbf{t}}{25,763}$} & \multirow{3}{*}{$\begin{array}{c}\begin{array}{c}\text { Anlamlılık } \\
\text { Düzeyi }\end{array} \\
, 000\end{array}$} \\
\hline & & \multirow{2}{*}{$\frac{\text { B }}{2,499}$} & \multirow{2}{*}{$\frac{\text { Std. Hata }}{, 097}$} & & & \\
\hline 1 & Sabit & & & & & \\
\hline & $\begin{array}{l}\text { Covid-19 } \\
\text { Korkusu }\end{array}$ & ,201 & 035 & 326 & 5,694 & ,000 \\
\hline
\end{tabular}

a.Bağımlı Değiş̧ken: Tükenmişlik $\left(R^{2}=, 106 ;\right.$ Düzeltilmiş $R^{2}=, 103 ; F=32,420 ; p=0,00$; $\mathrm{DW}: 1,823 ; \mathrm{VIF}=1)$

\begin{tabular}{|c|c|c|c|c|c|c|}
\hline & & \multicolumn{2}{|c|}{$\begin{array}{c}\text { Standartlaştırılmamış } \\
\text { Katsayılar }\end{array}$} & \multirow{2}{*}{\begin{tabular}{|c|}
$\begin{array}{c}\text { Standartlaştırılmıs } \\
\text { Katsayılar }\end{array}$ \\
Beta \\
\end{tabular}} & \multirow[b]{2}{*}{$\mathrm{l}$} & \multirow{2}{*}{$\begin{array}{l}\text { Anlamlılık } \\
\text { Düzzeyi }\end{array}$} \\
\hline \multicolumn{2}{|c|}{ Model } & B & Std. Hata & & & \\
\hline \multirow[t]{2}{*}{1} & Sabit & 1,898 & , 157 & & 12,103 &, 000 \\
\hline & $\begin{array}{l}\text { Covid-19 } \\
\text { Korkusu }\end{array}$ &, 331 & ,057 &, 332 & 5,810 &, 000 \\
\hline
\end{tabular}

a.Bağımlı Değişken: Duygusal Tükenme $\left(\mathrm{R}^{2}=, 110\right.$; Düzeltilmiş $\mathrm{R}^{2}=, 107 ; \mathrm{F}=33,760 ; \mathrm{p}=0,00$ DW:1,702; VIF=1)

\begin{tabular}{|l|l|c|c|c|c|c|}
\hline \multicolumn{2}{|c|}{} & \multicolumn{2}{|c|}{$\begin{array}{c}\text { Standartlaştırılmamış } \\
\text { Katsayılar }\end{array}$} & $\begin{array}{c}\text { Standartlaştırılmış } \\
\text { Katsayılar }\end{array}$ & \multirow{2}{*}{ Anlamlılık } \\
\cline { 2 - 7 } Model & B & Std. Hata & Beta & t & \begin{tabular}{c} 
Düzeyi \\
\hline 1
\end{tabular} \\
\cline { 2 - 7 } & Sabit & 1,839 &, 163 & & 11,271 &, 000 \\
\cline { 2 - 7 } & $\begin{array}{l}\text { Covid-19 } \\
\text { Korkusu }\end{array}$ &, 215 &, 059 &, 215 & 3,624 &, 000 \\
\hline
\end{tabular}

a.Bağımlı Değişken: Duyarsızlaşma $\left(R^{2}=, 046 ;\right.$ Düzeltilmiş $R^{2}=, 043 ; F=13,135 ; p=0,00$; DW:1,788; VIF=1)

\section{SONUÇ VE ÖNERILER}

Turizm sektörü sürekli gelişmekte olan bir sektör olmanın yanında hassas ve kırılgan yapısıyla emeğin yoğun olduğu sektörler arasında yer almaktadır. Turizm işletmeleri yapısı gereği siyasi olaylar, finansal krizler, salgın hastalıklar, terörizm ve sosyal olaylardan en fazla etkilenen sektörler arasında yer almaktadır (Köşker, 2017: 216). Tüm dünyada etkisini gösteren Covid-19 salgını, hizmetin ve emeğin yoğun olduğu restoran işletmelerini de derinden etkilemiştir. Cinnioğlu (2021: 36) yapmış olduğu çalışmada, Covid-19 sürecinde turizm işletmelerinin bir kısmının faaliyetlerine ara vermek zorunda olduğunu ve bazı işletmelerin eksik istihdam ile faaliyetlerini gerçekleştirme çabası içinde olduğunu 


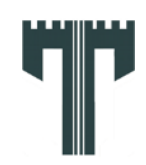

Gastroia: Journal of Gastronomy and Travel Research, Vol. 5, Issue 3, 447-463, 2021

Restoran Çalışanların Covid-19 Korkusu ile Tükenmişlik Düzeyleri Arasındaki İlişkinin Belirlenmesi: Hatay Örneğ $i$

Seyran REYHANDALI, Hasan CINNIOĞLU

belirtmiştir. Benzer bir çalışmada turizm işletmelerinin faaliyetlerini durdurması, finansal olarak işletmelere ve çalışanlara yansımış ve birçok çalışanın işsiz kalmasına neden olduğu belirtilmiştir. (Alaeddinoğlu ve Rol, 2020: 235). Bu doğrultuda insanlarda oluşan iş stresi, geçim ve gelecek kaygısı, ruhsal olarak insanları olumsuz etkilemekte, umutsuzluğu ve tükenmişliği de beraberinde getirmektedir. Bu bilgiler 1şığında araştırmanın temel amacı; Hatay ilinde faaliyet gösteren restoran işletmelerinde çalışanların Covid-19 korkusu ile tükenmişlik düzeyleri arasındaki ilişkiyi belirlemektir. Buna bağlı olarak çalışanlarda Covid19 korkusunun tükenmişliğin alt boyutları olan duygusal tükenme, duyarsızlaşma ve düşük kişisel başarının çalışanlar üzerindeki etkilerini belirlemek bu çalışmanın alt amaçları arasında yer almaktadır. Bu amaç doğrultusunda, literatür de yer alan daha önceki çalışmalardan yararlanılarak kavramsal çerçeve oluşturulmuş ve kavramsal çerçeve göz önüne alınarak araştırmanın hipotezleri geliştirilmiş̧ir. Elde edilen hipotezlerin analizi için, Hatay ilinde faaliyet gösteren restoran çalışanlarından toplamda 274 anket toplanmış ve veriler analiz edilmiştir. Katılımcıların tükenmişlik düzeyleri incelendiğinde; ölçeğinin alt boyutlarının da orta düzeyde olduğu belirlenmiştir. Bununla birlikte katılımcıların Covid 19 korku düzeylerinin ise yine orta düzeyde $(2,60)$ olduğu görülmektedir. Araştırma kapsamında bir temel hipotez ve üç alt hipotez geliştirilmiştir. Yapılan analiz sonucunda; çalışanların Covid-19 korkusu ve tükenmişlik düzeyleri arasında pozitif yönlü ve anlamlı bir ilişki olduğu tespit edildiğinden araştırmanın temel hipotezi kabul edilmiştir. Diğer bir ifadeyle, restoran çalışanlarının Covid-19 korku düzeyi arttıkça tükenmişlik düzeylerinin de arttığı belirlenmiştir. Araştırma sonuçlarına göre katılımcıların Covid-19 korku düzeyi ile kişisel başarı düzeyi arasında herhangi bir anlamlı ilişki tespit edilmemiştir. Bu sonuca göre restoran çalışanlarındaki Covid-19 korkusu sahip oldukları kişisel başarı düzeyini etkilememektedir. Mion vd. (2021: 175) yaptıkları araştırmada da pandeminin insanlar üzerindeki etkisi incelenmiştir. Özelikle araştırma sonucunda Covid-19 korkusunun insanların tükenmişlik duyguları üzerinde çok büyük etkisi olduğu belirlenmiştir. Benzer şekilde Denning vd (2021: 2) yapmış oldukları araştırmada çalışanların Covid-19 korkusunun tükenmişlik üzerinde pozitif bir etkiye sahip olduğu ifade edilmiştir. Bununla birlikte Sasangohar vd (2020: 106), çalışmalarında Covid-19 pandemisinin kişiler üzerinde stres, kayı ve tükenmiş̧lik gibi birçok olumsuz etkiye neden olabileceğini belirtmişlerdir.

Covid-19 salgınını önlemek amacıyla bir dizi tedbir, kısıtlamalar ve karantina uygulanmıştır. $\mathrm{Bu}$ alınan önlemler sonucunda birçok işyerinin faaliyetini durdurması ve insanların işsiz kalması, insanlarda tükenmişliğe varan fiziksel ve psikolojik sorunların ortaya çıkmasına neden olmuştur (Ulutaşdemir, 2021: 397). Yumru (2020: 5)'de sağlık çalışanlarına yönelik yapmış olduğu benzer bir araştırmada, Covid-19 salgın sürecinde artan çalışma saatleri ve virüse yakalanma riski gibi durumların olması ile beraber sağlık çalışanlarının emeğini yok sayan her türlü davranış ve söylemlerin çalışanları duygusal olarak tükenmişlik yaşamalarına neden olduğunu belirtmiştir. Türkili vd., (2021:354) sağlık çalışanlarına yönelik yapmış oldukları araştırmada çalışanların pandemi sürecinde, kişisel koruyucu ekipmanlarının yetersiz olması, yüksek bulaş riski ve tedavinin kanıtlanmamış olması gibi faktörlerin var olması duyarsızlaşmayı ve duygusal tükenmeyi arttırdığı yönünde sonuçlar tespit etmiştir. Tükenmişliğin alt boyutları açısından bakıldığında Covid-19 korkusu ile duygusal tükenme arasında pozitif yönlü ve anlamlı, yine aynı şekilde duyarsızlaşma arasında pozitif yönlü ve anlamlı bir ilişki tespit edilmiştir. Ancak bu ilişkilere rağmen Covid-19 korkusu ile kişisel başarı arasında herhangi bir ilişki tespit edilmemiştir. 


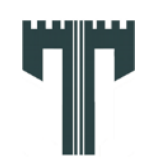

Gastroia: Journal of Gastronomy and Travel Research, Vol. 5, Issue 3, 447-463, 2021

Restoran Çalışanların Covid-19 Korkusu ile Tükenmişlik Düzeyleri Arasındaki İlişkinin Belirlenmesi: Hatay Örneğ $i$

Seyran REYHANDALI, Hasan CINNIOĞLU

Covid-19 sürecinde, Hatay ilinde faaliyet gösteren restoran işletmesinde çalışanlara yönelik yapılan bu çalışma, anket sonuçlarına göre değerlendirilmiş, nicel bir çalışmadır. Konuyla ilgili çalışma turizm işletmelerinde faaliyet gösteren diğer işletme çalışanlarına nitel yöntemler ile yapılabilir. Restoran çalışanlarına yapılan bu araştırma aynı zamanda bu süreçten çalışanlar kadar etkilenen restoran işletme sahiplerine ve müşterilere de yapilabilir. Benzer çalışmanın farklı illerde ve bölgelerde yapılması farklı sonuçları da ortaya koyabilir.

\section{KAYNAKÇA}

Ahorsu, D. K., Lin, C. Y., Imani, V., Saffari, M., Griffiths, M. D. ve Pakpour, A. H. (2020). The fear of covid-19 scale. Development and initial validation. International Journal of Mental Health and Addiction, 1-9.

Alaeddinoğlu, F. ve Rol, S. (2020). Covid-19 pandemisi ve turizm üzerindeki etkileri. Yüzüncü Y1l Üniversitesi Sosyal Bilimler Enstitüsü Dergisi, (Salgın Hastalıklar Özel Say1s1), 233-258.

Arpaci, I., Karataş, K. ve Baloğlu, M. (2020). The development and initial tests for the psychometric properties of the covid-19 phobia scale (C19P-S). Personality and Individual Differences, 164, 110108.

Atay, L. (2020). Covid-19 salgını ve turizme etkileri. Seyahat ve Otel İşletmeciliği Dergisi, 17(1), 168-172.

Aydın, B. ve Doğan, M. (2020). Yeni koranavirüs (covıd-19) pandemisinin turistik tüketici davranışları ve Türkiye turizmi üzerindeki etkilerinin değerlendirilmesi, Pazarlama Teorisi ve Uygulamalar1 Dergisi, 6(1), 93-115.

Bakar, N. A. ve Rosbi, S. (2020). Effect of coronavirus disease (COVID-19) to tourism industry. International Journal of Advanced Engineering Research and Science, 7(4), 189-193.

Barua, S. (2020). Understanding coronanomics: The economic implications of the coronavirus (COVID-19) pandemic, SSRN 3566477. 1-44.

Birdir, K. ve Tepeci, M. (2003). Otel genel müdürlerinde tükenmişlik sendromu ve tükenmişliğin genel müdürlerin işlerini değiştirme eğilimlerine etkisi, Anatolia: Turizm Araştırmaları Dergisi, 14(2), 93-106.

Bozkurt, Y., Zeybek, Z. ve Aşkın, R. (2020). Covid-19 pandemisi: Psikolojik etkileri ve terapötik müdahaleler. İstanbul Ticaret Üniversitesi Sosyal Bilimler Dergisi, 19(37), 304-318.

Budak, G. ve Sürgevil, O. (2005). Tükenmişlik ve tükenmişliği etkileyen örgütsel faktörlerin analizine ilişkin akademik personel üzerinde bir uygulama. Dokuz Eylül Üniversitesi İktisadi ve İdari Bilimler Fakültesi Dergisi, 20(2), 95-108.

Chohan, K., Fetzer, K., Heiser, S. R. ve Norman, S. (2020). From burnout to wellness: Using appreciative inquiry to shift midmichigan health towards a strengths-based perspective. Master of applied positive psychology (MAPP) service learning projects, $1-49$. 


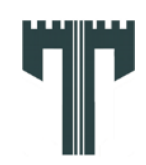

Gastroia: Journal of Gastronomy and Travel Research, Vol. 5, Issue 3, 447-463, 2021

Restoran Çalışanların Covid-19 Korkusu ile Tükenmişlik Düzeyleri Arasındaki İlişkinin Belirlenmesi: Hatay Örneğ $i$

Seyran REYHANDALI, Hasan CINNIOĞLU

Cinnioğlu, H., Salha, H. ve Yazıt, H. (2017). Yiyecek içecek işletmelerinde çalışan işgörenlerin psikolojik sözleşme ihlal algılarının tükenmişlik düzeyleri üzerine etkisi Tekirdağ örneği. Sosyal Bilimler Araştırma Dergisi, 6(4), 45-58.

Cinnioğlu, H., ve Salha, H. (2017). Turizm İşletmelerinde İşgörenlerin Tükenmişlik Seviyelerinin Bazı Değişkenlere Göre Karşılaştırılması, III. IBANESS Congress Series - Edirne / Turkey, March 04-05,

Cinnioğlu, H., Atay, L. ve Karakaş, E. (2019). Algılanan liderlik tarzının tükenmişlik düzeyine etkisi: Çanakkale otel işletmelerinde bir araştırma. Anemon Muş Alparslan Üniversitesi Sosyal Bilimler Dergisi, 7(6), 157-165.

Cinnioğlu, H. (2021). Covid 19 pandemi sürecinde otel yöneticilerinin sergiledikleri liderlik davranışları: İstanbul örneği. Türk Turizm Araştırmaları Dergisi, 5(1), 34-46.

Çelik, A. ve Saçl1, Ç. (2013). Burnout Syndrome Among Hotel Employees: The Case Of The City Of Konya. Economic and Environmental Studies, 13(3), 28, 353-364

Demir, M., Günaydın, Y. ve Demir, Ş. Ş. (2020). Koronavirüs (Covid-19) salgınının Türkiye'de turizm üzerindeki öncülleri, etkileri ve sonuçlarının değerlendirilmesi. International Journal of Social Sciences and Education Research, 6(1), 80-107.

Denning M, Goh ET, Tan B, Kanneganti A, Almonte M, Scott A, et al. (2021) Determinants of burnout and other aspects of psychological wellbeing in healthcare workers during the Covid-19 pandemic: A multinational cross-sectional study. PLOS ONE, 16(4):1-18.

Gann, M. L. (1979). The role of personality factors and job characteristics in burnout: A study of social service workers. Unpublished Doctoral Dissertation, University of California at Berkeley. 1-143.

Golembiewski, R. T., Boudreau, R. A., Sun, B. C. ve Luo, H. (1998). Estimates of burnout in public agencies: Worldwide, how many employees have which degrees of burnout and with what consequences? Public Administration Review, 58(1), 59-65.

Gormeli Kurt, N. ve Gunes, C. (2020). How has covid-19 pandemic affected crowded emergency services? International Journal of Clinical Practice, 74(12).

Griffith, A. K. (2020). Parental burnout and child maltreatment during the covid-19 pandemic. Journal of Family Violence, 1-7. https//doi.org/10.1007/s10896-020-00172$2,1-7$.

Hall, C. M. (2010). Crisis events in tourism: Subjects of crisis in tourism. Current İssues in Tourism, 13(5), 401-417.

Haywood, K.M. (2020). A post covid-19 future - tourism reimagined and reenabled, Tourism Geographies, 22(3), 599-609.

İflazoğlu, N. ve Aksoy, M. (2020). Tüketicilerin covıd-19 salgını sürecinde yiyecek-içecek işletmelerinden bekledikleri hizmetin niteliğine ilişkin bir araştırma. Journal of Tourism and Gastronomy Studies, 8(4), 3362-3377.

İslamoğlu, A. H. \& Alnıaçı, Ü. (2014). Sosyal Bilimlerde Araştırma Yöntemleri, Beta Basım, İstanbul 


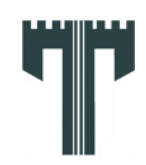

Gastroia: Journal of Gastronomy and Travel Research, Vol. 5, Issue 3, 447-463, 2021

Restoran Çalışanların Covid-19 Korkusu ile Tükenmişlik Düzeyleri Arasındaki İlişkinin Belirlenmesi: Hatay Örneğ $i$

Seyran REYHANDALI, Hasan CINNIOĞLU

Kaçmaz, N. (2005). Tükenmişlik (burnout) sendromu. İstanbul Tıp Fakültesi Dergisi, 68(1), 29-32.

Köşker, H. (2017). Krizlerin turizm sektörüne etkileri üzerine bir araştırma. 2016 yılı Türkiye örneği. Akademik Bakış Uluslararası Hakemli Sosyal Bilimler Dergisi, (62), 216-230.

Morina, S. M. ve Avdimetaj, S. K. (2020). Impact of legal and economic measures on the management of global pandemic covid-19 in the Western Balkans. Tam Metin Bildiriler Kitab1-Sosyal Bilimler, 121.

Maslach, C. ve Jackson, S. E. (1981). The measurement of experienced burnout. Journal Of Occupational Behaviour, 2, 99-113.

Maslach, C., Jackson, S. E. ve Leiter, M. (1996). Maslach Burnout İnventory (3rd ed.). Palo Alto, CA: Consulting psychologists press. 191-218.

Mion, G., P. Hamann, M. Saleten, B. Plaud, C. Baillard. (2021). Psychological impact of the COVID-19 pandemic and burnout severity in French residents: A national study, The European Journal of Psychiatry, 35(3), 173-180.

Okat, Ç., Bahçeci, V. ve Ocak, E. (2020). COVİD-19 (Yeni Koronavirüs) salgınının neden olduğu krizin yiyecek içecek işletmeleri üzerindeki etkisinin değerlendirilmesi. Uluslararası Güncel Turizm Araştırmaları Dergisi, 4(2), 201-218.

Pelit, E. ve Türkmen, F. (2008). Otel İşletmeleri İşgörenlerinin Tükenmişlik Düzeyleri: Yerli ve Yabancı Zincir Otel İşletmeleri İşgörenleri Üzerinde Bir Araştırma. Gazi Üniversitesi İktisadi ve İdari Bilimler Fakültesi Dergisi, 10 (1), 117-139.

Polizzi, C., Lynn, S. J. ve Perry, A. (2020). Stress and coping in the time of covid-19: Pathways to resilience and recovery. Clinical Neuropsychiatry, 17(2).

Rada, R. E. ve Johnson-Leong, C. (2004). Stress, burnout, anxiety and depression among dentists. The Journal of the American Dental Association, 135(6), 788-794.

Sasangohar, F.,, SM, MASc, J., Stephen L. Masud, Faisal N., Vahidy, Farhaan S., Kash, Bita A., (2020). Provider Burnout and Fatigue During the COVID-19 Pandemic: Lessons Learned From a High-Volume Intensive Care Unit, The Open Mind, 131(1), 106-111.

Satici, B., Gocet-Tekin, E., Deniz, M. E. ve Satici, S. A. (2020). Adaptation of the fear of COVID-19 Scale: Its association with psychological distress and life satisfaction in Turkey. International Journal of Mental Health and Addiction, 1-9.

Sulkowski, L. (2020). Covid-19 pandemic; Recession, virtual revolution leading to deglobalization? Journal of Intercultural Management, 12(1), 1-11.

T.C. Sağlık Bakanlığı (2020). Covid-19 (SARS-CoV-2 Enfeksiyonu) rehberi. Halk Sağlığı Genel Müdürlüğü, Bilim Kurulu Çalışması, Ankara.

Türkili, S., Uysal, Y., Tot, Ş. ve Mert, E. (2021). Aile hekimlerinde korona virüs salgını nedeniyle yaşanılan zorluklar, kaygı ve tükenmişlik durumlarının incelenmesi. Turkish Journal of Family Medicine and Primary Care, 15(2), 348-356. 


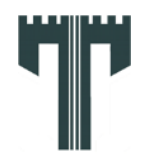

Gastroia: Journal of Gastronomy and Travel Research, Vol. 5, Issue 3, 447-463, 2021

Restoran Çalışanların Covid-19 Korkusu ile Tükenmişlik Düzeyleri Arasındaki İlişkinin Belirlenmesi: Hatay Örneğ $i$

Seyran REYHANDALI, Hasan CINNIOĞLU

Uluğ, B. D. (2020). COVID-20 ruhsal bozukluklar pandemisi mi olacak? Türk Psikiyatri Dergisi, 31(4), A3-A4.

Ulutaşdemir, N. (Ed). (2021). Covid 19 pandemisinde sağlık hizmetleri 1. İksad Yayınevi.

Ural, A. ve Kılıç, İ. (2013). Bilimsel araştırma süreci ve SPSS ile veri analizi. Ankara: Detay Yayıncilık.

Üstün, Ç. ve Özçiftçi, S. (2020). COVID-19 pandemisinin sosyal yaşam ve etik düzlem üzerine etkileri: bir değerlendirme çalışması, Anadolu Kliniği Tıp Bilimleri Dergisi, 25(1), 142-153.

Yumru, M. (2020). COVID-19 ve sağlık çalışanlarında tükenmişlik, Klinik Psikiyatri, 23(1), 5-6.

Yükselen, C. (2017). Pazarlama araştırmaları, 7. Baskı, Ankara: Detay Yayıncılık.

World Health Organization. WHO Director-General's opening remarks at the media briefing on COVID-19-11 March 2020. Geneva, Switzerland: World Health Organization; 2020. 